\title{
The Pragmatic Transfer of Javanese Sojourners' English in Conversation Strategies
}

\author{
Dwijani Ratnadewi \\ dwijani_ratnadewi@fkip.um-surabaya.ac.id \\ Universitas Muhammadiyah Surabaya, Surabaya, Indonesia
}

\begin{abstract}
The use of home cultural schemas in English interactions in an English-speaking host country as a form of discrepancy leading to misunderstanding. This study investigated the pragmatic transfer phenomenon, namely the use of Javanese culture in English conversation. It aimed at finding an occurrence of pragmatic transfer in the Javanese English conversation in the host country; the conversation strategies the transfer takes place, and the tendency of pragmatic transfer in the conversational strategies. The data were collected through semi-structured interviews and field notes. The analysis used the narrative analysis using vital emergent themes based on the pragmatic transfer principle, the conversational strategy, and the Javanese norms. The result indicated the availability of negative and positive pragmatic transfer in four strategies: making the most of others' praise, indirect response, denial over compliments, mitigating taboo or imposition marked with Javanese terms, idioms, and jargon insertion. Besides, motivation is an essential aspect that determines the existence of pragmatic transfer in English interactions.
\end{abstract}

Keywords: Pragmatic transfer, Conversation strategies; Javanese norms

\section{INTRODUCTION}

Being in a new environment with a new culture, sojourners need modification and acquisition of their own home into the new host culture schemas, which means altering and managing the native to adapt to the new culture (Nishida, 2005). This includes integrating values, beliefs, and behaviors from the native culture into their new cultural worldview (Chan, 2014). As members of the weaker groups, sojourners are compelled to accept aspects of the host culture community, causing changes in their native/home culture. To adapt to a new environment, pragmatic competence of the host culture, language and appropriateness is the goal of this adaptation. It is part of communicative capability and maintains an ongoing negotiation of meaning and purpose through language use (Chan, 2014). Pragmatic competence produces meaning intended, felt, and anticipated in various contexts, cultures, channels, and even media (Kramsch \& Hua, 2016).

To achieve this pragmatic competence, cultural differences become a significant obstacle, like Javanese as a society with high context culture, which is more unspoken, implicit, and highly relies on context is different from Australia. In this low context culture society, communication prioritizes direct verbal communication. The difference is quite 
significant, considering that Javanese has principles that have been preserved and practiced among Javanese people until now. They are hiding true feelings, avoiding open conflict and being silent as better and commendable (Wiryomartono, 2016), prioritizing togetherness, respect (Suseno, 1985), modesty, harmony, empathy, feeling awkward toward a respectful person, responsive in implicit signs and feeling aware of one's position (Sukarno, 2010). When this is maintained in conversations in the host language, it can be considered a pragmatic transfer.

The pragmatic transfer is encouraged or hindered from specific contexts (Ifantidou, 2017); this transferability constraint might be caused by some sociolinguistics factors influenced by native culture context. The pragmatic transfer is negative when interfering and positive when facilitating meaning. Pragmatic transfer phenomena were found in various cases seen in some researchers' works. The first is the fact that the high proficiency foreign language learners had lower pragmatic transfers, due to their ample control over the second/foreign language ( $\mathrm{Bu}, 2012)$, they also used reversed pragmatic transfers like acceptance strategies in their mother tongue, which were more like English in responding compliments (Cao, 2016). Alhadidi (2017) found out that the first language transfer was higher in the group of Saudi English beginners. Thus the pragmatic transfer rate decreased as their level of English language proficiency developed. The pragmatic transfer occurred on some types of refusal of various language speakers. Some are seen in the refusal of Persian foreign language learners (Hashemian, 2012), which looked a lot like their first language; in the Iraqi Arabic native speakers who neglected to apply 'verbal' refusal strategy (Al Qunayeer, 2019; Turki et al., 2020), also in the Javanese learners of English refusal variety which was similar more to that of native Javanese refusal (Wijayanto, 2016). Positive, pragmatic transfers were found in rejection that reflected some socio-cultural aspects related to the first language, such as non-verbal rejection and mention of God in English (Darwish, 2018). As seen in retaining the first language habits and communication patterns, pragmatic transfer was found when the speakers used another language. This was seen in timid and vague hedges that were considered the first language rhetorical construction influence (Alonso et al., 2012) and in various English texts written by Afrikaans who relied on Afrikaans pragmatic patterns (Kruger \& van Rooy, 2016).

The above studies examined the occurrence of pragmatic transfer in a specific particular strategy in conversation or writing, for example, the presence of pragmatic transfer in a refusal, in gender language, on hedges, on positive or negative transfers. 
This study examines a pragmatic transfer indication in various emerging strategies embracing all the strategies observed in the above studies, including essential consideration towards related cultural aspects in understanding the phenomena. This study examined the phenomenon that marked the emergence of pragmatic transfer in the host environment. The aims were to find an occurrence of pragmatic transfer in the Javanese English conversation in the host country, under what conversation strategies the transfer takes place, and see how far the pragmatic transfer appears in the strategies.

\section{METHOD}

This research applied the qualitative ethnographic ways of observing Javanese culture phenomena, and this is an ethnographic effort to understand utterances (Whittle \& Butler, 2018; Vo et al., 2019; Jensen et al., 2020). The research respondents were Javanese native speakers from the Mataraman area (Central Java and the western part of East Java Province of Indonesia) consisting of 13 Javanese native speakers. They have stayed in English-speaking countries for more than two years. They stayed in Perth, Melbourne, and Adelaide. The research's primary data were the respondents' English utterances taken from conversations, the secondary data containing the respondents' background, and other supporting data, like education and personal motivation. Data collection was an unstructured, open-ended interview protocol, and the key instrument was the researcher herself. Demographic questionnaires were given in advance to acquire the proposed sampling of the respondents. The data were analyzed through the following successive steps: develop the concept, categorize, code, and interpret the data-the transcribed utterances framed by foregrounding (Akita, 2020) the utterances based on the phenomena sought. The narrative analysis was applied using the vital emergent themes from the data. The selective focus was adopted based on the pragmatic transfer principle, the conversation strategy, and the Javanese norms.

\section{RESULTS AND DISCUSSION}

The pragmatic transfer phenomenon was found in how the respondents applied Javanese patterns and ways of interacting with others through a choice of words, phrases, sentences, kinship terms, idioms, metaphors, and jokes. This pragmatic transfer phenomenon is indicated in the conversation strategies discussed in the following discussion. 


\section{The Negative and Positive Pragmatic Transfer}

The pragmatic transfer is an interference towards the host language and culture due to the home language and culture's influence. It can be temporary or permanent depending on various things such as motivation, communication needs, language environment, language exposure, and other causes. The pragmatic transfer can be negative or positive, negative if it interferes with meaning, providing multiple interpretations, misunderstanding, or failure to understand. Meanwhile, it is positive when it facilitates understanding meaning because there are similarities of the home and host word meaning. The use of Javanese language habits was found in English conversations, so that this form is believed to be a form of pragmatic transfer. The following are the forms of the pragmatic transfer in the respondents' conversation strategies in English utterances. The strategies found were illustrated in Table 1.

Table 1. The Pragmatic Transfer in Conversation Strategies

\begin{tabular}{ll}
\hline Strategies & Negative/Positive \\
\hline Making the most of others' praise & Using Kinship terms (-) \\
Indirect Response & Applying Implicature (-) \\
& Creating jokes with jargon $(-)$ \\
& Using non-deictic pronoun $(+)$ \\
Denial over compliments & Making use of idioms $(-)$ \\
& Creating Humour $(-)$ \\
Mitigating taboo or imposition & Applying Implicature $(-)$ \\
& Using Metaphor $(-)$ \\
& Using Modal auxiliary $(+)$ \\
\hline
\end{tabular}

\section{a. Making the Most of Others' Praise}

The negative pragmatic transfer phenomenon was seen by applying certain forms of addressing others using Javanese and Indonesian ways in the respondents' English. Some forms of addressing in Javanese terms, such as pak 'sir,' bu 'ma'am'/'Mrs,' mas 'older brother' and mbak 'older sister,' remained in use they were speaking English. This structured and pragmatic addressing style is part of reaching the speaker's goals (Koentjaraningrat, 1989). This kind of practice was seen in some conversations, for example, in the utterance 'Maybe $B u$ 'Mrs' M (mentioning the husband's name) can play to Perth' instead of saying 'Maybe you can play to Perth' is likely to be a sign of the effort to apply the mutually understood addressing style vocabularies to facilitate and fulfill the intended meaning. The word bu 'ma'am' is used to greet mothers or adult women, such as friends, colleagues, or 
strangers, and express the aspect of kurmat 'respect' of the Javanese principles for maintaining relationships.

Among adults or married people, the Kromo style (formal Javanese speech style) addresses each other (Sukarno, 2010). Unless the interlocutors are close friends, the way of addressing people is usually in Kromo style. The respondents were not close friends, so the addressing term bu signifies panjenengan, the highest 'you' informal Javanese speech style; this way, the use of this kinship term is somehow raising the addressee' status to reach as high as this level of the word 'you' it represents. This way, the speaker respected the hearer through the kinship term, or at least the speaker wanted the hearer to have the notion that the speaker respected her. This implies that he preserved for Javanese unggah-ungguh 'norms' that should be applied in the respective situations.

\section{b. Indirect Response}

The use of Javanese concepts in English is likely to cause interference. The negative pragmatic transfer was seen in how the interlocutors saved face over sensitive topics that appeared with underlying cultural reasons. Given questions about polygamy, a female respondent seemed reluctant to accept or reject it openly; instead, she gave an implied meaning statement as in 'God give us think ... to think a... talk brain, good brain to think and somehow make sense of his teaching'. She answered the interviewer's question indirectly, while she must have been able to say 'I do not agree' or 'I do agree.' There is a possibility that she did not answer. First, it is the realm of religion, so it is an individual domain, none of your business aspects, so reluctance was performed. The second she tried to save the interviewer's face since she did not know which side the interviewer was on, both answers had consequences. Indirectness might save herself, and the interviewer could get the disagreement (if it were) less painfully. Still, adequate context is required to understand this implicature sentence. The concept of indirectness and the ability to understand it is included in the Javanese concept of tanggap ing sasmita 'responsive in signs' (Sukarno, 2010) which refers to a person's sensitivity to read and understand the sign given in the symbolic information (Koentjaraningrat, 1989). It is usually followed by laku ing sasmita amrih lantip, meaning 'practice to be sharp,' or a recommendation to learn to read the signs. All of these Javanese principles underlie the emergence of interference in English sentences. 
An indirect response was also seen in different utterances; it uses a humorous expression. Instead of thanking or rejecting a compliment, a respondent utilized a jargon to respond to it indirectly. The Javanese jargon of mangan ra mangan ngumpul, which means 'harmony must be maintained even if there is no food to eat,' refers to the Javanese old philosophy when Indonesia once experienced food crisis mangan 'having meals' was very desirable. In this instance, the need for food was made less critical compared to togetherness (Suseno, 1985). The jargon is often exploited as a lazy attitude to gather more for fun than to work for a living behind its textual meaning. She indirectly rejected the praise given to her by considering herself contrary to the compliment given. Besides, because this jargon has been deemed incompatible with the current situation, its use is usually aimed for a particular purpose, usually to create humor. The humor is created by changing some words. They are ra 'no' to yo 'yes' and tur 'also' into mangan yo mangan tur ngumpul becomes ultimately the opposite meaning 'the food and harmony,' it intentionally creates the humorous effect.

Different utterances illustrated other indirect responses, but because it facilitated the meaning of the sentence, it did not cause misunderstanding in English. This phenomenon of positive, pragmatic transfer, for example, was seen in the use of general or impersonal 'you' as seen in one of the respondents' statement: 'I cannot force you to follow me' and 'I cannot justify you as bad' when invited to comment on someone's behavior. Both the words 'you' are non-deictic use of pronoun referring to people in general about what is expected (Williams, 2020). The use of this pronoun seems to be relevant to a Javanese culture concept where people feel ewuh pakewuh 'awkward' (Koentjaraningrat, 1989) to talk about bad or sensitive things so that they will pretend or use other means to avoid hurting others' feeling in stating the topic. The use of the impersonal 'you' is a means to cover the awkward feeling when revealing unpleasant topics and avoid referring directly to the listener (Croft, 2020). The non-deictic form is much easier to apply to any level of addressees and saving face even more because it affects 'distancing' the speaker from the threat (González-Peña, 2020). There are similar expressions in English, such as you reap what you sow,' which may mean 'You finally have to face the consequences of your actions. Nevertheless, this is not used to avoid or indirectly responsible, but rather to remind someone like 'I told you'. Whereas in 
Javanese, the pattern is required to maintain each other's face to avoid conflict and retain peace to create awareness of balance and preserve human life (Amrih, 2008).

\section{c. Denial Over a Praise}

The phenomena of negative pragmatic transfer were also seen in how some respondents denied themselves overpraise, the laudable Javanese way of refusing (Wijayanto, 2016). After being complimented, a respondent stated an idiom of 'I do not know,' according to Merriam-Webster dictionary, the idiom 'I do not know' is used to express disagreement, uncertainty, or doubt. However, this meaning is not used to respond to a compliment, a person is generally grateful for the praise, and the saying of 'thank you' is the most common. Javanese people believe that humility is a trait that one wants, so when someone praises, you have to disagree with her or show that you do not deserve it. Therefore, it seems that the respondent used this intention to deny the praise. Another respondent reacted by lowering or denigrating (Sukarno, 2010) herself, stating, 'I do not know anything, I am terrible.' She might perform the Javanese andhap-asor 'modesty' principle (Amrih, 2008), which recommends Javanese to lower/humble themselves. Although this is a seemingly self-defeating statement, the reasons for doing this are not pretending or negligence of telling the truth. This is more likely to avoid the arrogant impression (Sukarno, 2010) when she was praised for being profitable or successful. The refusal to use the first language path is similar to Hashemian's findings (Hashemian, 2012).

Reacting to compliments that a respondent and friends were successful people, she performed an act of denying signified as lowering oneself by stating the utterance of 'we are pringas-pringis' 'like to perform a wry smile, smirk' or similar other meaning. This Javanese negative nuance phrase is often used to tease or remind close friends, younger people, or children, but certainly not for the elderly, higher status, and influential people. The joke was meant to refer to themselves. It thus led to the image of lowering herself. Although the intention was shown in the form of jokes, the self-defeating or denigrating (Sukarno, 2010) was visible through the meaning contained in the humor. This negative impression of the Javanese expression was utilized to deny herself and her friends the praise given. This reinforces the notion that these Javanese people used the Javanese cultural schemas in their English. 


\section{d. Mitigating Taboo and Imposition}

In managing talks containing taboo and imposition, Javanese cultural mitigation was carried out. Taboo and imposition should be avoided and not discussed to maintain harmony because there is the principle of rukun agawe santosa 'harmony creates tranquility' and congkrah agawe bubrah 'conflicts makes disparity' (Hermawan et al., 2018) attached to the Javanese people. Therefore, such expressions must be refined so as not to cause unrest. Strategies to mitigate them were found in the data when the interviewer and one of the participants talked about polygamy concepts. In the utterance, 'I would like to look for another door to heaven than through that door.' The words 'door' for the followers is believed to be the reward to heaven, and look for another door' implied that she disagreed with the idea. The phrase 'another door' alleviates the rejection since the topic being discussed might be considered 'non-free good' (McGee, 2019) or taboo words to be talked about freely.

Some metaphors were found to reduce imposition, like the utterance found in the interview 'I want (to) eat egg' and 'I want (to) eat chicken' to illustrate a choice a man may face when he decides to marry another woman after his wife. Being hard to say bluntly, he made use of a metaphor to reduce the imposition. The representation of the concept of 'marrying' to 'eating' and 'a woman' to 'egg' and 'chicken' (food) seems rude. However, the Javanese metaphor is currently known among Javanese society as a mockery or a joke. In his research Darwis also confirmed indigenous socio-cultural knowledge in the foreign language (Darwish, 2018). Different kind of mitigation was found in the phrase 'may be' that mostly appear before the propositional utterances. As in '...I want (to) eat ..ee ... egg maybe ..' refinement of the somewhat taboo statement when he likened women to food. The English word 'maybe' to smooth out taboo expressions makes this phenomenon inclined to positive, pragmatic transfer.

The respondent's use of the repeated phrase 'may be' may illustrate the speaker's realization that his words were harsh and offended or gave himself a wrong impression for stating a specific horrible idea, so the phrase is used in advance. Alonso found this a fuzzy hedging (Alonso et al., 2012; Loi \& Lim, 2020) to soften statements (Gustilo et al., 2020). The different perception of taboo creates awkwardness in cross-culture communication. Specific taboo topics are universal, 
especially sexual or religious; yet, the kinds and degrees of taboo concept are culturally different and promote pragmatic transfer.

\section{The Pragmatic Transfer Tendency}

The need to survive in the host country makes sojourners struggle to acquire the host culture. Particular aspects influence the development of pragmatic competence in a host culture that impacts the emergence of the pragmatic transfer. This study found the respondents transferred back their first language's pragmatic force in their foreign/host language. This may be considered insufficient or developing pragmatic competence because this may encourage misunderstanding and hinder communication. Some facts may provide the reason why it happened. These belong to non-structural factors that affect the emergent of pragmatic transfer, namely, as also found by Darwish (Darwish, 2018), some socio-cultural factors (Önal \& Turgut, 2017) like home and host cultural schemas, degree of interaction (exposure) with the host society and other factors like host language proficiency, length of stay and motivation.

The host language proficiency surely helps when people first live abroad (IsabelliGarcía et al., 2018; Corder et al., 2018; George, 2019); nevertheless, this is not yet sufficient to mingle with the host society. The occurrence of pragmatic transfer was found in the utterances of some respondents with English proficiency, which is not the same as the previous research (Alhadidi, 2017; Bu, 2012; Zhu, 2018), saying that pragmatic transfer decreases when English proficiency is high. Meanwhile, length of stay does not automatically develop pragmatic competence (Eslami \& Ahn, 2014; Barron, 2019). Other aspects like motivation and degree of interaction with the host society were found to impact the growth of the foreign/host schemas. Nishida states that those who are sufficiently motivated may abandon the home schemas and modify their cognitive structures accordingly (Nishida, 2005). This is similar to the previous research finding (Eslami \& Ahn, 2014) that motivation has a positive effect on pragmatic competence. It may determine the kind and degree of the pragmatic transfer found. Table 2 illustrates the phenomenon; the difference in motivation leads to weakening or reinforcing the pragmatic transfer in their English.

Several motivations marked the willingness to interact with the local community, namely high motivation, moderate motivation as an instrumental reason to get a job or study, and no or low motivation to integrate with the host community. These motivations affected other aspects such as choosing residence to be in the same 
location with home people or not, the side or main jobs, the activities, and contact with the host people. This kind of motivation accelerates and decelerates the pragmatic transfer. The higher the motivation to acquire the host language and culture, the greater the effort to communicate with host people. The faster the host culture's understanding, the less pragmatic transfers were found in their language and vice versa. This phenomenon is seen in Table 2, where the low group used many indigenous jokes with jargon, expressions, implicatures, and metaphors. In contrast, the high group still utilized implicatures, but Javanese expressions and jargons did not appear, and the moderate group used balanced strategies.

Table 2. Pragmatic Transfer Tendency

\begin{tabular}{|c|c|c|c|c|c|c|c|c|c|}
\hline \multirow{2}{*}{$\begin{array}{l}\text { Strategies } \\
\\
\text { Group }\end{array}$} & \multirow{2}{*}{ 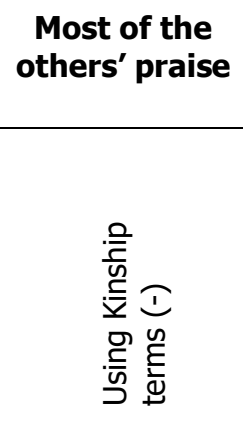 } & \multicolumn{2}{|c|}{$\begin{array}{l}\text { Indirect } \\
\text { Response }\end{array}$} & \multicolumn{3}{|c|}{$\begin{array}{l}\text { Denial over } \\
\text { compliments }\end{array}$} & \multicolumn{3}{|c|}{$\begin{array}{l}\text { Mitigating taboo or } \\
\text { imposition }\end{array}$} \\
\hline & & 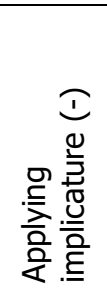 & 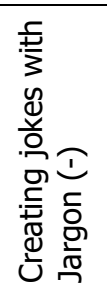 & 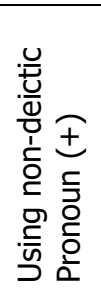 & 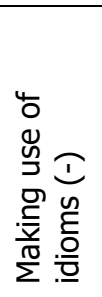 & 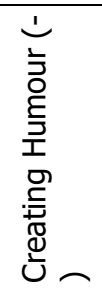 & 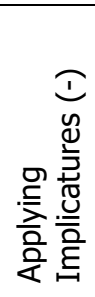 & 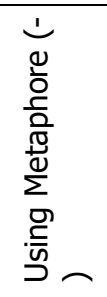 & 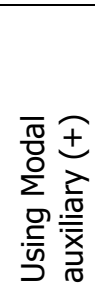 \\
\hline $\begin{array}{l}\text { Highly } \\
\text { motivated }\end{array}$ & -+ & + & - & + & - & - & + & - & - \\
\hline Moderate & + & + & + & -+ & -+ & -+ & -+ & + & + \\
\hline
\end{tabular}

This research implies that having specific foreign language proficiency is not yet a guarantee of mingling with the host society well; one must also have the pragmatic competence of the host society's culture. In addition to good foreign language acquisition, intensive communication with native speakers needs to be created and maintained for the pragmatic competence to grow and develop. Consequently, a person who studies a foreign language in his/her own country may be able to acquire the language but cannot grow the pragmatic competence of the background culture of the foreign language learned, so what might happen is speaking a foreign language but thinking and using his cultural norms. If this happens to a foreign language teacher, then the thinking schemas will spread to his students. This implication requires further research that proves that this is true and to see what impact it may have. 


\section{CONCLUSION}

The pragmatic transfer was found in conversation strategies that describe the phenomenon of "speaking English with Javanese thinking schemas." There was negative and positive pragmatic transfer found in four conversation strategies. They were making the most of others' praise; indirect response, denial over compliments, and mitigating taboo or imposition. In these strategies, interference of home culture was seen. The kinship terms are used to raise people's status, apply implicature, employ humor with jargon, and express indirect strategies. Humor was also found in denial toward compliments, including the use of non-deictic pronouns and idioms. Implicatures, metaphors, and modal auxiliary were mainly seen as mitigation towards unwanted expression. The tendency to use the pragmatic transfer in English utterances affected by several aspects such as host language proficiency, host culture schemas, length of stay, motivation, and degree of interaction (exposure) with the host society. Besides, it seems that the motivational aspect of integrating with the host community is the most important one, which ultimately affects their degree of pragmatic competence. This pragmatic competence promotes and inhibits the emergence of pragmatic transfer in their English. The motivation can be high, moderate, or low/no motivation to acquire the host language and culture and resulted in the acceleration or deceleration of their host culture schemas figured out in the pragmatic transfer found in their utterances.

\section{REFERENCES}

Akita, K. (2020). A typology of depiction marking: The prosody of Japanese ideophones and beyond. Studies in Language. https://doi.org/10.1075/sl.17029.aki.

Al Qunayeer, H. S. (2019). Refusal strategies in L1 and L2 among undergraduate Saudi EFL learners. International Journal of English and Education, 8(4), 145-172.

Alhadidi, A. H. (2017). Investigating the Effect of L1 Pragmatic Transfer on the Acquisition of English Language by Saudi Speakers. International Journal of Linguistics, 9(4), 63. https://doi.org/10.5296/ijl.v9i4.10911.

Alonso, R. A., Alonso, M. A., \& Mariñas, L. T. (2012). Hedging: An exploratory study of pragmatic transfer in nonnative English readers' rhetorical preferences. Iberica, 23, 47-64.

Amrih, P. (2008). Ilmu Kearifan Jawa. Pinus.

Barron, A. (2019). Pragmatic development and stay abroad. Journal of Pragmatics, 146, 43-53. https://doi.org/10.1016/j.pragma.2019.05.003.

$\mathrm{Bu}, \mathrm{J}$. (2012). A study of relationships between L1 pragmatic transfer and L2 proficiency. English Language Teaching, 5(1), 32-43. https://doi.org/10.5539/elt.v5n1p32

Cao, M. (2016). Backward Pragmatic Transfer: An Empirical Study on Compliment Responses among Chinese EFL Learners. Theory and Practice in Language Studies, 6(9), 1846. https://doi.org/10.17507/tpls.0609.18.

Chan, D. (2014). Acculturation: A Social Identity Approach. Lincoln University, Christchurch. 
Corder, D., Roskvist, A., Harvey, S., \& Stacey, K. (2018). Language teachers on study abroad programmes: The characteristics and strategies of those most likely to increase their intercultural communicative competence. In Second Language Study Abroad (pp. 257297). Palgrave Macmillan, Cham.

Croft, W. (2020). Basics of Construction Grammar. In Ten Lectures on Construction Grammar and Typology (pp. 1-32). Brill.

Darwish, A. (2018). Socio-pragmatic Transfer in Egyptian Refusals. Athens Journal of Philology, 5(3), 179-200. https://doi.org/10.30958/ajp.5-3-2

Eslami, Z. R., \& Ahn, S.-J. (2014). Motivation, amount of interaction, length of residence, and $\{\{\mathrm{ES}\} \mathrm{L}\}$ learners' pragmatic competence. Applied Research on \{English\} Language, 3(1), 9-28.

George, A. (2019). Study abroad homestay versus dormitory: Extralinguistic factors and regional features. Spanish in Context, 16(1), 77-103.

González-Peña, P., Doherty, M. J., \& Guijarro-Fuentes, P. (2020). Acquisition of Demonstratives in English and Spanish. Frontiers in Psychology, 11.

Gustilo, L., Vergel, M. I., \& Valle, A. (2020). Digital writing and English teachers' attitudes towards its non-standard conventions. The Asian EFL Journal Quarterly, 101.

Hashemian, M. (2012). Cross-cultural differences and pragmatic transfer in English and Persian refusals. The Journal of Teaching Language Skills (JTLS), 4(3), 23-46.

Hermawan, A., Arief, M., \& Rahayu, W. P. (2018). Dimensions of the Javanese culture and the role of Parents in instilling values in creative industry entrepreneurship. International Journal of $\begin{array}{llll}\text { Engineering and Technology (UAE), } & \text { 182-189. }\end{array}$ https://doi.org/10.14419/ijet.v7i2.29.13313.

Ifantidou, E. (2017). Pragmatic transfer, relevance and procedural meaning in L2. International Review of Pragmatics, 9(2), 82-133. https://doi.org/10.1163/18773109-00901003.

Isabelli-García, C., Bown, J., Plews, J. L., \& Dewey, D. P. (2018). Language learning and study abroad. Language Teaching, 51(4), 439-484.

Itakura, H. (2002). Gender and pragmatic transfer in topic development. Language, Culture and Curriculum, 15(2), 161-183. https://doi.org/10.1080/07908310208666641.

Jensen, P. R., Cruz, J., Eger, E. K., Hanchey, J. N., Gist-Mackey, A. N., Ruiz-Mesa, K., \& Villamil, A. (2020). Pushing beyond positionalities and through "failures" in qualitative organizational communication: Experiences and lessons on identities in ethnographic praxis. Management Communication Quarterly, 34(1), 121-151.

Koentjaraningrat. (1989). The Jacanese Culture. Oxford University Press.

Kramsch, C., \& Hua, Z. (2016). Language and culture in ELT. In G. Hall (Ed.) (Ed.), Routledge Handbook of English Language Teaching (pp. 38-50). Routlege.

Kruger, H., \& van Rooy, B. (2016). Syntactic and pragmatic transfer effects in reported-speech constructions in three contact varieties of English influenced by Afrikaans. Language Sciences, 56, 118-131. https://doi.org/10.1016/j.langsci.2016.04.003.

Loi, C. K., \& Lim, J. M. H. (2019). Hedging in the discussion sections of English and Malay Educational Research Articles. GEMA Online $\mathbb{B}$ Journal of Language Studies, 19(1).

McGee, P. (2019). Cross-cultural pragmatic failure. Training, Language and Culture, 3(1), 73-84. https://doi.org/10.29366/2019tlc.3.1.5.

Nishida, T. (2005). Cultural Scheme Theory. In W. B. Gudykunst (Ed.), Theorizing About Intellectual Communication (p. 401). Sage Publication.

Önal, G. K., \& Turgut, H. (2017). Cultural schema and design activity in an architectural design studio. Frontiers of architectural research, 6(2), 183-203. 
Sukarno. (2010). The Reflection of the Javanese Cultural Concepts in the Politeness of Javanese. Kata, 12(1), 59-71.

Suseno, F. M. (1985). Etika Jawa, Sebuah Analisa Fasafi tentang Kebijaksanaan Hidup Jawa. Gramedia.

Turki, H. Y., Hussein, J. Q., \& Al-Kubaisy, A. A. (2020). Cross-Sectional Study of Refusal Speech Act Used by Iraqi Undergraduate Students: Of English in Relation to the Academic Level. Koya University Journal of Humanities and Social Sciences, 3(1), 166-173. https://doi.org/10.14500/kujhss.v3n1y2020.pp166-173.

Vo, V., Auroy, L., \& Sarradon-Eck, A. (2019). Patients' perceptions of mHealth apps: metaethnographic review of qualitative studies. JMIR mHealth and uHealth, 77), e13817.

Whittle, C., \& Butler, C. (2018). Sexuality in the lives of people with intellectual disabilities: A metaethnographic synthesis of qualitative studies. Research in developmental disabilities, 75, 68-81.

Wijayanto, A. (2016). Variability of refusal in L2: Evidence of L1 pragmalinguistic transfer and learner's idiosyncratic usage. International Journal of Applied Linguistics (United Kingdom), 26(1), 99-119. https://doi.org/10.1111/ijal.12081.

Williams, N. (2020). Deixis and Indexicals. The International Encyclopedia of Linguistic Anthropology, 1-9.

Wiryomartono, B. (2016). Javanese culture and the Meanings of Locality. Studies on Arts, Urbanism, Polity and Society. Lexington Book.

Zhu, D. (2018). A Study of the Relationship between L2 Proficiency and Pragmatic Transfer in the Speech Act of Criticism. International Journal of Language \& Linguistics, 5(4), 59-66. https://doi.org/10.30845/ijll.v5n4p7. 